Scientific paper

\title{
Two New Mononuclear Manganese(III) Salen Complexes
}

\author{
Sabina Grabner, Peter Bukovec and Nina Lah* \\ University of Ljubljana, Faculty of Chemistry and Chemical Technology, Večna pot 113, 1000 Ljubljana; \\ * Corresponding author: E-mail: nina.lah @fkkt.uni-lj.si \\ Received: 16-09-2014
}

Dedicated to the memory of Prof. Dr. Jurij V. Brenčič.

\begin{abstract}
Two new Mn(III)-salen complexes with 4-aminopyridine (4-apy) have been prepared and structurally characterized. [Mn(ac)(4-apy)(sal)], 1, exhibits mononuclear molecular structure with an octahedral environment around the Mn center. The salen ligand occupies all four basal positions, while the axial sites are occupied by endocyclic nitrogen atom of the 4-apy ligand and acetato oxygen atom. [Mn(4-apy) ${ }_{2}(\mathrm{sal}) \mathrm{PF}_{6}, \mathbf{2}$, is an ionic compound in which the coordination cations, $\left[\mathrm{Mn}(4-\mathrm{apy})_{2}(\mathrm{sal})\right]^{+}$, exhibit octahedral geometry. Both axial sites are occupied by endocyclic nitrogen atoms of the 4-aminopyridine ligands. Cations are connected into zig-zag chains via $\mathrm{H}$-bonds. The positive charge is compensated by $\mathrm{PF}_{6}{ }^{-}$anions located between the chains.
\end{abstract}

Keywords: manganese(III) complexes, salen, 4-aminopyridine, acetate

\section{Introduction}

Manganese plays an important role in metalloenzymes, notably in manganese catalase, manganese superoxide dismutase and in the water oxidizing complex in photosystem II of green plants. ${ }^{1-4}$ Manganese(III) complexes, particularly with Schiff base type ligands, have been studied extensively as structural and functional models for metalloenzymes. ${ }^{5-6}$ Among them, complexes with "salen type" ligands have received much attention. Of the many manganese salen ( $N, N$ '-ethylenebis(salicylimine), sal) complexes reported as biomimetic models $[\mathrm{Mn}(\mathrm{sal}) \mathrm{Cl}]$ has been recognized as an efficient reactive oxygen species scavenger in vivo prolonging the life of C. elegans and preventing the DNA damage in human spermatozoa. ${ }^{7,8}$ Additionally, several complexes with $\mathrm{MnN}_{2} \mathrm{O}_{2}$ chromophore have been studied as epoxidation catalysts. ${ }^{9-12}$

All these observations prompted us to prepare new manganese(III) complexes which besides salen ligand (sal) contain additional ligands. 4-aminopyridine (4-apy) was chosen as a neutral nitrogen donor ligand and acetate (ac) as an oxygen donor ligand. Acetate has often been used to model the coordination environment at the enzyme active sites with carboxylate rich amino acids (aspartic or glutamic) participating in the coordination to the metal

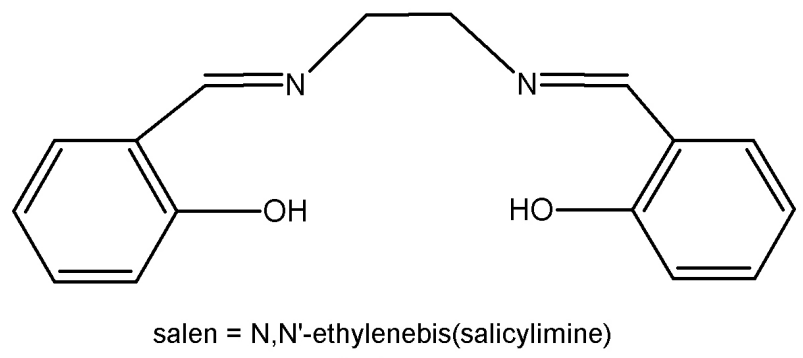

(sal)

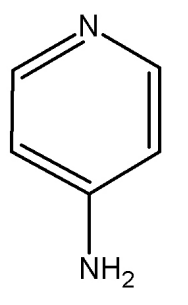

4-aminopyridine (4-apy)<smiles>CC(=O)[O-]</smiles>

acetate

(ac)

Scheme 1. Ligands used in this work. 
center. Herein we report the synthesis and crystal structures of two new mononuclear coordination species: an ionic compound $\left[\mathrm{Mn}(4-\mathrm{apy})_{2}(\mathrm{sal})\right] \mathrm{PF}_{6}$ and molecular compound $[\mathrm{Mn}(\mathrm{ac})(4-\mathrm{apy})(\mathrm{sal})]$.

\section{Experimental Section}

\section{1. General Remarks}

Chemicals were purchased from Sigma-Aldrich and used as received. The infrared spectra were recorded with a Perkin Elmer 2000 Fourier Transform infrared spectrometer with an ATR sampling accessory. IR spectra are contained in the supplementary data file. Microanalyses were performed by the Chemistry Department service at the University of Ljubljana.

\section{Synthesis of [Mn(ac)(4-apy)(sal)], 1}

$N, N$ '-ethylenebis(salicylimine) $\quad(0.268 \mathrm{~g}, \quad 1.00$ $\mathrm{mmol})$ and manganese(II) acetate tetrahydrate $(0.502 \mathrm{~g}$, $2.05 \mathrm{mmol})$ in absolute ethanol $(25 \mathrm{~mL})$ were refluxed for 2 hours. The reaction mixture was evaporated under reduced pressure to dryness. A brown-red product was dissolved in hot water $(25 \mathrm{~mL})$ and the resulting solution was filtered. 4-aminopyridine $(0.193 \mathrm{~g}, 2.05 \mathrm{mmol})$ was added to a filtrate and the mixture was stirred for 2 hours at room temperature. Dark brown prismatic crystals of $\mathbf{1}$ were isolated from the obtained solution after slow evaporation at room temperature. Analysis calculated for $\mathrm{C}_{23} \mathrm{H}_{23} \mathrm{Mn}$ $\mathrm{N}_{4} \mathrm{O}_{4}: \mathrm{C}, 58.23 ; \mathrm{H}, 4.89 ; \mathrm{N}, 11.81 \%$; found: $\mathrm{C}, 58.50 ; \mathrm{H}$, $4.99 ; \mathrm{N}, 11.70 \%$.

\section{Synthesis of [Mn(4-apy $\left.)_{2}(\mathrm{sal})\right] \mathrm{PF}_{6}, 2$}

$N, N^{\prime}$-ethylenebis(salicylimine) $\quad(0.268 \mathrm{~g}, \quad 1.00$ $\mathrm{mmol})$ and manganese(II) acetate tetrahydrate $(0.502 \mathrm{~g}$, $2.05 \mathrm{mmol})$ in absolute ethanol $(25 \mathrm{~mL})$ were refluxed for 2 hours. The reaction mixture was evaporated under reduced pressure to dryness. A brown-red product was dissolved in hot water $(25 \mathrm{~mL})$ and the solution was filtered. 4-aminopyridine $(0.193 \mathrm{~g}, 2.05 \mathrm{mmol})$ was added to the filtrate and the mixture was stirred for 2 hours at room temperature. To the resulting brown solution $\mathrm{KPF}_{6}(660$ $\mathrm{mg}, 3.59 \mathrm{mmol}$ ) was added and the solution was kept at 4 ${ }^{\circ} \mathrm{C}$ for 2 hours. A brown precipitate was filtered off and dissolved in methanol ( $5 \mathrm{~mL})$. Dark brown prismatic crystals of $\mathbf{2}$ were isolated from the obtained solution after slow evaporation at room temperature. Analysis calculated for $\mathrm{C}_{26} \mathrm{H}_{26} \mathrm{MnN}_{6} \mathrm{O}_{2} \mathrm{PF}_{6}: \mathrm{C}, 47.72 ; \mathrm{H}, 4.00 ; \mathrm{N}, 12.84 \%$; found: $\mathrm{C}, 47.90 ; \mathrm{H}, 4.12 ; \mathrm{N}, 12.75 \%$.

\section{X-ray crystallography}

$\mathrm{X}$-ray data collections for compounds $\mathbf{1}$ and $\mathbf{2}$ were carried out on an Agilent SuperNova diffractometer at 150 $\mathrm{K}$ using $\mathrm{Cu} \mathrm{K} \alpha$ radiation $(\lambda=1.5484 \AA)$. CrysAlis PRO software $^{13}$ was used for the data collection, cell refinement and data reduction. The structures were solved by direct methods implemented in $\mathrm{SIR}^{14}$ and refined on $F^{2}$ using SHELX-9 $7^{15}$. Hydrogen atoms were placed in geometrically idealized positions and refined as riding on their parent atoms. All the non-hydrogen atoms of the coordination cation in compound $\mathbf{2}$ were successfully refined with anisotropic displacement parameters. The remaining considerable electron density was evidently due to the presence of a disordered $\mathrm{PF}_{6}{ }^{-}$anion. The disorder couldn't be modelled satisfactorily. Therefore, the initial data set was treated using the SQUEEZE routine ${ }^{16}$ to remove the contribution of the disordered $\mathrm{PF}_{6}{ }^{-}$anion. A summary of the crystallographic data and structure refinements is given in Table 1. The relevant geometric parameters are listed in Table 2 and Table 3.

Table 1. Crystallographic data for compounds 1 and 2.

\begin{tabular}{lll}
\hline & $\mathbf{1}$ & $\mathbf{2}$ \\
\hline Formula & $\mathrm{C}_{23} \mathrm{H}_{23} \mathrm{MnN}_{4} \mathrm{O}_{4}$ & $\mathrm{C}_{26} \mathrm{H}_{26} \mathrm{MnN}_{6} \mathrm{O}_{2} \mathrm{PF}_{6}$ \\
Formula weight $(\mathrm{g} / \mathrm{mol})$ & 474.39 & 654.44 \\
Crystal system & monoclinic & monoclinic \\
Space group & $P 2_{1} / c$ & $P 2_{1} / c$ \\
$a(\AA)$ & $9.4516(1)$ & $10.9871(1)$ \\
$b(\AA)$ & $17.7866(2)$ & $13.0760(1)$ \\
$c(\AA)$ & $13.0703(1)$ & $19.7349(2)$ \\
$\beta\left(^{\circ}\right)$ & $100.618(1)$ & $100.630(1)$ \\
$V\left(\AA^{3}\right)$ & $2159.65(4)$ & $2786.62(6)$ \\
$\mathrm{Z}^{\prime}(\mathrm{Z})$ & $4(4)$ & $4(4)$ \\
$T(\mathrm{~K})$ & 150 & 150 \\
Independent reflections & 4433 & 5702 \\
Observed reflections & 4144 & 4980 \\
{$[I>2 \sigma(I)]$} & & \\
Goodness-of-fit & 1.059 & 1.114 \\
$R_{1}($ all data) & 0.0441 & 0.0479 \\
$R_{1}[I>2 \sigma(I)]$ & 0.0414 & 0.0401 \\
$w R_{2}($ all data $)$ & 0.1137 & 0.1118 \\
$w R_{2}[I>2 \sigma(I)]$ & 0.1096 & 0.1041 \\
\hline
\end{tabular}

\section{Results and Discussion}

Reach Mn(III) chemistry with salen type ligands results in a large number of complexes with a high level of structural diversity. The Cambridge Structural Database ${ }^{17}$ contains 17 examples of structures with salen or its derivative and acetate being coordinated to a manganese center. Four structures are polymeric; the acetate ligand plays a bridging role in all of them. ${ }^{18-21}$ The dinuclear structure of the coordination species has been observed in five compounds. ${ }^{22-26}$ Acetate acts as a bridging ligand in four of them, while in one of the dimers phenolate oxygen of a substituted salen ligand serves as bridge between the two $\mathrm{Mn}$ (III) centers and the acetate is coordinated as a terminal ligand. Seven complexes possess mononuclear structure. Among them, six complexes are octahedral with a $\mathrm{MnN}_{2} \mathrm{O}_{2}$ basal plane. ${ }^{23,27-29}$ Acetate is coordinated as a monodentate ligand and occupies one axial site. The re- 
maining site is occupied by a $\mathrm{H}_{2} \mathrm{O}$ molecule in all six complexes. One example is reported with square pyramidal coordination around a manganese center. ${ }^{30}$ Its structure is similar to the octahedral complexes with a lack of an additional ligand on the axial site. A search through CSD revealed no examples of a mononuclear $\mathrm{Mn}$ (III)-salenacetate complex with an octahedral geometry in which the second axial site would be occupied by a neutral nitrogen donor ligand as observed in the case of [Mn(ac)(4-apy) (sal)], 1, reported herein.

Octahedral $\mathrm{Mn}(\mathrm{III})$ species with a $\left[\mathrm{Mn}(\mathrm{sal}) \mathrm{N}_{2}\right]^{+}$cation, where $\mathrm{N}_{2}$ denotes two neutral nitrogen donor ligands at the axial sites, are less frequent. There is only one example with such stoichiometry reported so far for the compound with imidazole as a neutral $\mathrm{N}$-donor ligand. ${ }^{31}$ The positive charge is compensated with the $\mathrm{PF}_{6}{ }^{-}$anion, similar to the ionic compound with 4-aminopyridine $\left[\mathrm{Mn}(4-\mathrm{apy})_{2}(\mathrm{sal})\right] \mathrm{PF}_{6}, \mathbf{2}$, presented here.

\section{Crystal structure of [Mn(ac)(4-apy)(sal)], 1}

Compound 1 crystallizes in the monoclinic space group $P 2_{1} / c$ with one $\mathrm{Mn}(\mathrm{ac})(4-\mathrm{apy})(\mathrm{sal})$ molecule in the asymmetric unit (Figure 1). The manganese ion is six coordinated and possesses $\mathrm{MnN}_{3} \mathrm{O}_{3}$ distorted octahedral geometry. The equatorial positions are occupied by salen donor atoms $\left(\mathrm{N}_{2} \mathrm{O}_{2}\right)$, while the axial sites are occupied by endocyclic $\mathrm{N}$-atom of the 4-apy ligand and one of acetate O-atoms. By inspection of Table 2 it can be seen that the equatorial metal-ligand bond lengths are similar and span the range of 1.8899(13)-1.9990(14) $\AA$, while the axial bond lengths to 4-apy and acetate moieties are longer: 2.3290(15) and 2.1854(14) ^, respectively. The significant difference in axial bond lengths should be pointed out. Particularly, the Mn1-N11 distance is rather long and

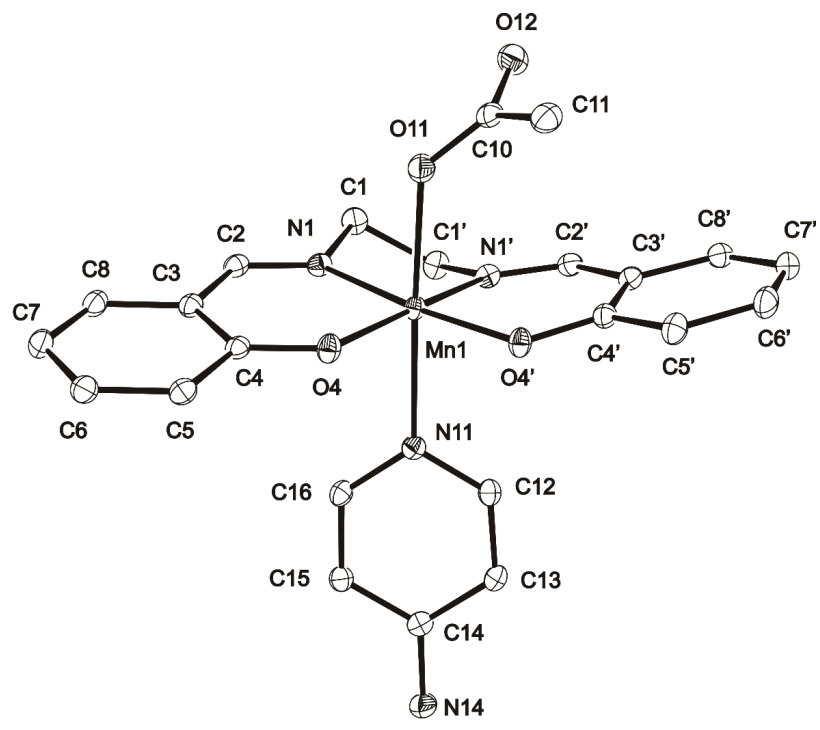

Figure 1. An ORTEP view of a compound 1, [Mn(ac)(4-apy)(sal)], showing $30 \%$ probability ellipsoids and the labeling scheme for non-hydrogen atoms. Hydrogen atoms are omitted for clarity. is considered to be one of the longest $\mathrm{Mn}-\mathrm{N}$ distances observed in $\mathrm{Mn}$ (III) compounds. The amino group on the para position to the coordinated pyridine $\mathrm{N}$-atom is involved in hydrogen bond with the non-coordinated oxygen atom of the acetate ligand from the adjacent molecule. The result is the formation of linear chains (Figure 2) propagated along the $a c$ diagonal. The arrangement of four symmetry related chains in the space is depicted in Figure 3.

Table 2. Selected geometric parameters for compound $\mathbf{1},[\mathrm{Mn}(\mathrm{ac})$ (4-apy)(sal)].

\begin{tabular}{llll}
\hline Mn1-N1 & $1.9990(14)$ & O4-Mn1-O4' & $94.96(5)$ \\
Mn1-N1' & $1.9899(15)$ & O4-Mn1-N1' & $171.62(6)$ \\
Mn1-O4 & $1.8899(13)$ & O4'-Mn1-N1' & $91.22(6)$ \\
Mn1-O4' & $1.8950(12)$ & O4-Mn1-N1 & $91.80(6)$ \\
Mn1-O11 & $2.1854(14)$ & O4'-Mn1-N1 & $173.01(6)$ \\
Mn1-N11 & $2.3290(15)$ & N1'-Mn1-N1 & $82.23(6)$ \\
& & O4-Mn1-O11 & $94.43(6)$ \\
N1'-Mn1-O11 & $91.05(6)$ & O4'-Mn1-O11 & $91.59(6)$ \\
N1-Mn1-O11 & $86.11(6)$ & O4-Mn1-N11 & $89.35(6)$ \\
O4'-Mn1-N11 & $88.59(6)$ & N1'-Mn1-N11 & $85.14(6)$ \\
N1-Mn1-N11 & $93.26(5)$ & O11-Mn1-N11 & $176.19(5)$ \\
\hline
\end{tabular}

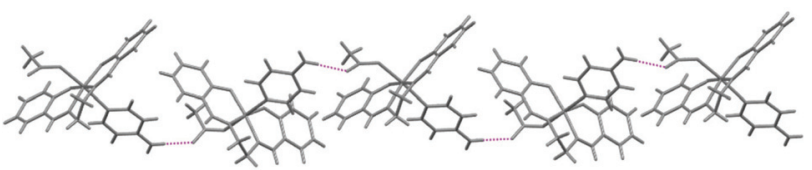

Figure 2. One-dimensional infinite chain of $[\mathrm{Mn}(\mathrm{ac})(4-\mathrm{apy})(\mathrm{sal})]$, 1. Hydrogen bonds of $\mathrm{N}-\mathrm{H} \cdots \mathrm{O}$ type are drawn as violet dashed lines.

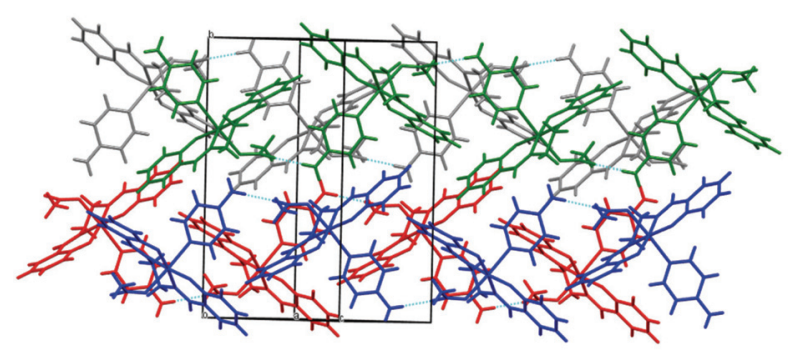

Figure 3. Packing view of compound 1 showing four symmetry related infinite chains colored red, blue, green and grey.

\section{Crystal structure of $\left[\mathrm{Mn}(4-\mathrm{apy})_{2}(\mathrm{sal})\right] \mathrm{PF}_{6}, 2$}

Compound $\mathbf{2}$ is ionic and crystallizes in the monoclinic space group $P 2_{1} / c$ with one coordination cation $\left[\mathrm{Mn} \text { (4-apy) }{ }_{2} \text { (sal) }\right]^{+}$and one $\mathrm{PF}_{6}{ }^{-}$anion in the asymmetric unit. An ORTEP-view of the coordination cation is presented in Figure 4. As expected, a manganese ion adopts a six coordinated distorted octahedral coordination geometry. Equatorial $\mathrm{N}_{2} \mathrm{O}_{2}$ atoms belong to the salen ligand while the apical sites are occupied by 4 -apy ligands which are coordinated to the metal ion through the endocyclic nitrogen atom. Selected geometric parameters 
are listed in Table 3. Pyridine rings of the 4-aminopyridine ligands are twisted with respect to each other. The angle between the planes of the two crystallographically different 4-apy ligands is $60.00(7)^{\circ}$. In addition, the pyridine ring $\mathrm{N} 11-\mathrm{C} 16$ is tilted towards the equatorial plane of the salen ligand by $64.15(5)^{\circ}$, while the pyridine ring $\mathrm{N} 21-\mathrm{C} 26$ is almost perpendicular to the salen plane $\left(88.78(5)^{\circ}\right)$. The hydrogen bonding network cannot be described properly due to the problems with the exact location of the disordered $\mathrm{PF}_{6}{ }^{-}$anions. Both amino groups are able to participate in the formation of $\mathrm{H}$-bonded structure and are probably involved as donors to fluorine atoms of the $\mathrm{PF}_{6}^{-}$anions. However, we can reliably report only the geometry of one $\mathrm{N}-\mathrm{H} \cdots \mathrm{O}$ type contact between the amino group and the oxygen atom of the salen ligand from the neighboring coordination species (Table 4). The result is the formation of zig-zag chains of coordination

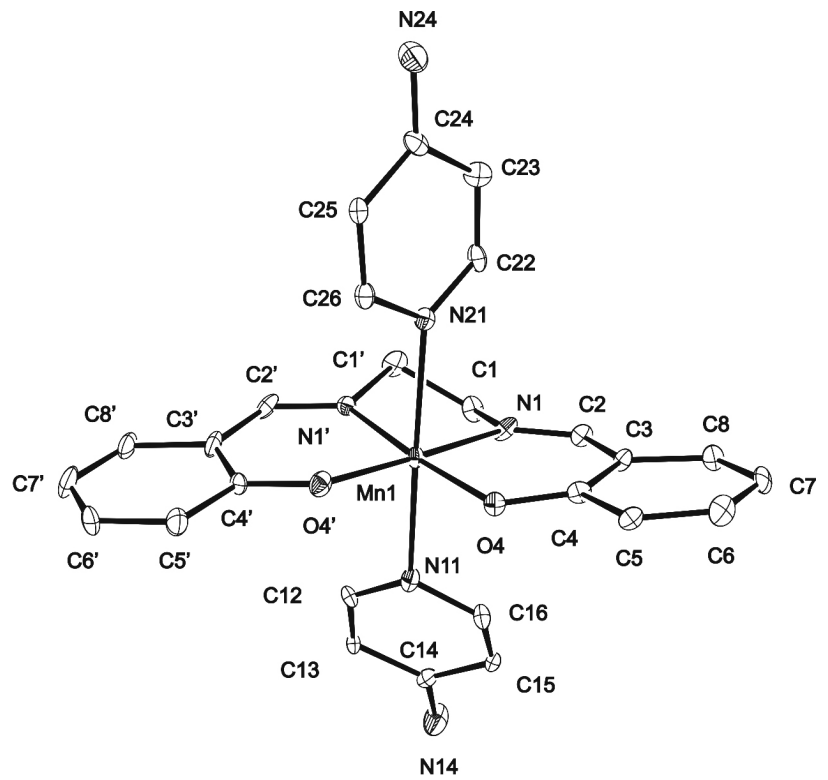

Figure 4. An ORTEP view of a cation in compound 2, [Mn(4apy $\left.)_{2}(\mathrm{sal})\right] \mathrm{PF}_{6}$, showing the $30 \%$ probability ellipsoids and the labeling scheme for non-hydrogen atoms. Hydrogen atoms are omitted for clarity.

Table 3. Selected geometric parameters for compound 2.

\begin{tabular}{llll}
\hline Mn1-N1 & $1.9889(12)$ & O4'-Mn1-O4 & $93.71(7)$ \\
Mn1-N1' & $1.9940(18)$ & O4'-Mn1-N1 & $174.3387)$ \\
Mn1-O4 & $1.8922(15)$ & O4-Mn1-N1 & $91.65(7)$ \\
Mn1-O4' & $1.8703(16)$ & O4'-Mn1-N1' & $92.07(7)$ \\
Mn1-N11 & $2.3432(19)$ & O4-Mn1-N1' & $174.05(7)$ \\
Mn1-N21 & $2.3548(19)$ & N1-Mn1-N1' & $82.63(7)$ \\
& & O4-Mn1-N11 & $92.03(7)$ \\
N1-Mn1-N11 & $84.15(7)$ & O4'-Mn1-N11 & $93.78(7)$ \\
N1'-Mn1-N11 & $89.00(7)$ & O4-Mn1-N21 & $93.09(7)$ \\
O4'-Mn1-N21 & $91.75(7)$ & N11-Mn1-N21 & $172.20(7)$ \\
O4-Mn1-N21 & $93.09(7)$ & N1-Mn1-N21 & $89.83(7)$ \\
N1'-Mn1-N21 & $85.31(7)$ & N11-Mn1-N21 & $172.20(7)$ \\
\hline
\end{tabular}

cations propagated along the $b$ axis (Figure 5). The packing diagram (Figure 6) shows the arrangement of the chains resulting in the formation of channels in which the disordered $\mathrm{PF}_{6}^{-}$anions are situated.

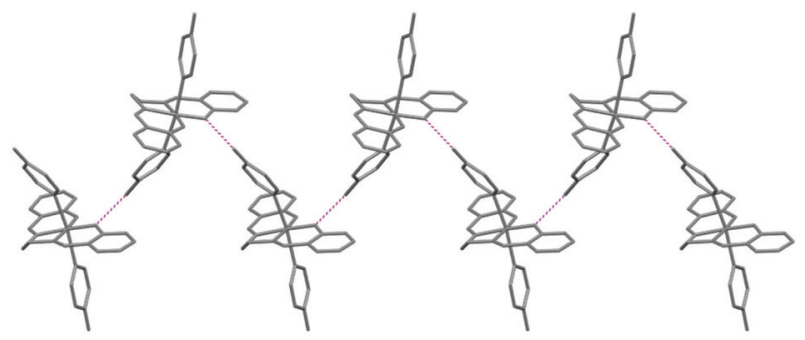

Figure 5. View of a zig-zag infinite chain in compound 2.

Table 4. Hydrogen-bond distances $(\AA)$ and angles $\left(^{\circ}\right)$ in compounds $\mathbf{1}$ and $\mathbf{2}$.

\begin{tabular}{lcclc}
\hline $\mathrm{D}-\mathrm{H} \cdots \mathrm{A}$ & $\mathrm{D}-\mathrm{H}$ & $\mathrm{H} \cdots \mathrm{A}$ & $\mathrm{D} \cdots \mathrm{A}$ & $\mathrm{D}-\mathrm{H} \cdots \mathrm{A}$ \\
$\mathbf{1}$ & & & & \\
$\mathrm{N} 14-\mathrm{H} 14 \mathrm{~b} \cdots \mathrm{O} 12^{\mathrm{i}}$ & 0.86 & 2.01 & $2.868(2)$ & 176.4 \\
$\mathbf{2}$ & & & & \\
$\mathrm{N} 14-\mathrm{H} 14 \mathrm{a} \cdots \mathrm{O} 4^{\mathrm{ii}}$ & 0.86 & 2.22 & $3.038(3)$ & 159.2 \\
\hline
\end{tabular}

Symmetry codes: i) $x+1,-y+0.5, z+0.5$; ii) $-x+1, y-0.5,-z+0.5$

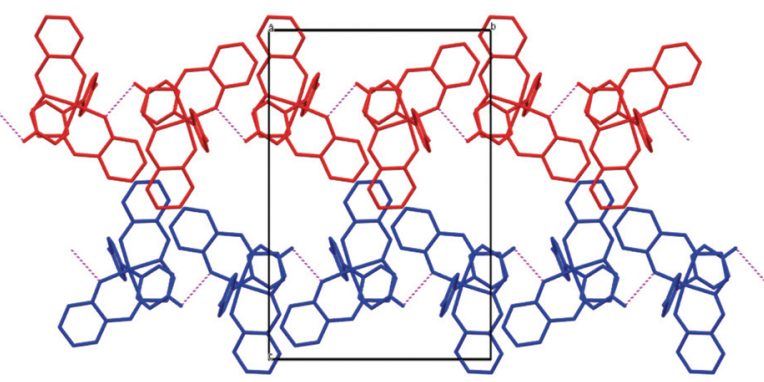

Figure 6. A packing diagram of compound 2 viewed along $a$ axis. Note the formation of channels which are filled by disordered $\mathrm{PF}_{6}{ }_{6}$ anions.

\section{Conclusions}

In summary, two new mononuclear manganese(III) coordination species have been prepared and structurally characterized. Their structures contribute to the richness of $\mathrm{Mn}(\mathrm{III})$ chemistry and indicate possible catalytic activity in dismutase reactions. A study of their SOD mimic activity is in progress.

\section{Acknowledgements}

The financial support of the Slovenian Research Agency through the grants P1-0175 and P1-0134 is grate- 
fully acknowledged. The EN-FIST Centre of Excellence is acknowledged for the use of the SuperNova diffractometer.

\section{Supplementary Material}

CCDC-1017716 (1) and CCDC-1017717 (2) contain the supplementary crystallographic data for this paper. The data can be obtained free of charge from The Cambridge Crystallographic Data Centre via www.ccdc. cam.ac.uk/data_request/cif. Supplementary data associated to this article can be found in the online version.

\section{References}

1. V. L. Pecoraro, Manganese Redox Enzymes, VCH Publisher, New York, 1992, pp. 355-422.

2. W. F. Beyer, I. Fridovich, Biochemistry 1985, 24, 6460 6467. http://dx.doi.org/10.1021/bi00344a023

3. R. H. Holm, P. Kennepohl, E. I. Solomon, Chem. Rev. 1996, 96, 2239-2314. http://dx.doi.org/10.1021/cr9500390

4. A. W. Rutherford, A. Boussac, Science 2004, 303, 17821784. http://dx.doi.org/10.1126/science. 1096767

5. M. J.Gunter, P. Turner, Coord. Chem. Rev. 1991, 108, 115161. http://dx.doi.org/10.1016/0010-8545(91)84001-L

6. T. Katsuki, Coord. Chem. Rev. 1995, 140, 189-214. http://dx.doi.org/10.1016/0010-8545(94)01124-T

7. S. Melov, J. Ravenscroft, S. Malik, M. S. Gill, D. W. Walker, P. E. Clayton, D. C. Wallace, B. Malfroy, S. R. Doctrow, G. J. Lightgow, Science 2000, 289, 1567-1569. http://dx.doi.org/10.1126/science.289.5484.1567

8. S. Lamond, M. Watkinson, T. Rutherford, K. Laing, A. Whiting, A. Smallwood, G. Nargund, S. Campbell, S. Banerjee, Reproduct. Biomed. Online 2003, 7, 407-418. http://dx.doi.org/10.1016/S1472-6483(10)61884-6

9. K. Srinivasan, P. Michaud, J. K. Kochi, J. Am. Chem. Soc. 1986, 108, 2309-2320. http://dx.doi.org/10.1021/ja00269a029

10. E. M. McGarrigle, D.G. Gilheany, Chem. Rev. 2005, 105, 1563-1602. http://dx.doi.org/10.1021/cr0306945

11. T. Katsuki in Catalytic Asymmetric Synthesis, Editor I. Ojima, Wiley, New York, 2000, 287.

12. A. R. Silva, C. Freire, B. de Castro, New J. Chem. 2004, 28, 253-260 and references therein. http://dx.doi.org/10.1039/b309125b

13. Agilent, CrysAlis PRO 2011. Agilent Technologies, Yarnton, Oxfordshire, England.
14. A. Altomare, M. C. Burla, M. Camalli, G. L. Cascarano, C. Giacovazzo, A. Guagliardi, A. G. G. Moliterni, G. Polidori, R. Spagna, J. Appl. Cryst. 1999, 32, 115-119. http://dx.doi.org/10.1107/S0021889898007717

15. G. M. Sheldrick, Acta Cryst. Sect. 2008, A64, 112-122. http://dx.doi.org/10.1107/S0108767307043930

16. P. van der Sluis, A. L. Spek, Acta Cryst. 1990, A46, 194-201. http://dx.doi.org/10.1107/S0108767389011189

17. F. H. Allen, Acta Cryst. 2002, B38, 380-388. http://dx.doi.org/10.1107/S0108768102003890

18. J. E. Davies, B. M. Gatehouse, K. S. Murray, J. Chem. Soc. Dalton Trans. 1973, 2523-2527. http://dx.doi.org/10.1039/dt9730002523

19. F. Akhtar, M.G.B. Drew, Acta Cryst. 1982, B38, 612-614. http://dx.doi.org/10.1107/S0567740882003525

20. G. E. Assey, A. M. Butcher, R. J. Butcher, Y. Gultneh, Acta Cryst. 2010, E66, m1384-m1385.

21. T. Glaser, M. Heidemeier, H. Theil, A. Stammler, H. Boegge, J. Schnack, Dalton Trans. 2010, 39, 192-199. http://dx.doi.org/10.1039/B912593K

22. D. Martinez, M. Motevalli, M. Watkinson, Dalton Trans. 2010, 39, 446-455. http://dx.doi.org/10.1039/B913865J

23. M. Sutradhar, L. M. Carrella, E. Rentschler, Polyhedron 2012, 38, 297-303. http://dx.doi.org/10.1016/j.poly.2012.03.021

24. M. Suzuki, T. Ishikawa, A. Harada, S. Ohba, M. Sakamoto, Y. Nishida, Polyhedron 1997, 16, 2553-2561. http://dx.doi.org/10.1016/S0277-5387(97)00003-X

25. Y. Kani, S. Ohba, Yu. Nishida, Acta Cryst. 2000, C56, e194.

26. Z. Lu, M. Yuan, F. Pan, S. Gao, D. Zhuang, D. Zhu, Inorg. Chem. 2006, 45, 3538-3548. http://dx.doi.org/10.1021/ic0516481

27. K. Ha, Z. Kristallogr. - New Cryst. Struct. 2010, 225, 285287.

28. M. Watkinson, M. Fondo, M. R. Bermejo, A. Sousa, C. A. McAuliffe, R. G. Pritchard, N. Jaiboon, N. Aurangzeb, M. Naeem, Dalton Trans. 1999, 31-41. http://dx.doi.org/10.1039/a805555f

29. J. Pauly, M. Winter, K. Hegetschweiler, M. F. Hazenkamp, F. Bachmann, J. Dannacher, Z. Kristallogr. - New Cryst. Struct. 2001, 216, 477-478. http://dx.doi.org/10.1524/ncrs.2001.216.14.499

30. G. Margraf, J. W. Bats, M. Wagner, CSD Private Communication 2009, CSD refcode: COTMOO.

31. A. Haikarainen, J. Sipila, P. Pietikainen, A. Pajunen, I. Mutikainen, Bioorg. Med. Chem. 2001, 9, 1633-1638. http://dx.doi.org/10.1016/S0968-0896(01)00053-0 


\section{Povzetek}

Pripravili smo dve novi koordinacijski spojini mangana(III) s salenom (sal) in 4-aminopiridinom (4-apy) in ju strukturno okarakterizirali. [Mn(ac)(4-apy)(sal)], 1, kristalizira v monoklinski prostorski skupini $P 2_{1} / c$. Celotna molekula predstavlja asimetrično enoto, v kateri je manganov ion oktaedrično koordiniran. Donorski atomi selena zasedajo ekvatorialne lege, aksialni legi pa sta zasedeni z obročnim dušikovim atomom 4-aminopiridina in kisikovim atomom acetata. $\left[\mathrm{Mn}(4-\mathrm{apy})_{2}(\mathrm{sal})\right] \mathrm{PF}_{6}, 2$, je ionska spojina. Koordinacijski kation $\left[\mathrm{Mn}(4-a p y)_{2}(\mathrm{sal})\right]^{+}$ima oktaedrično zgradbo. Dušikovi atomi molekul 4-aminopiridina zasedajo aksialne lege. Kationi se preko vodikovih vezi povezujejo v pozitivno nabite cik-cak verige. Pozitivni naboj kompenzirajo $\mathrm{PF}_{6}^{-}$anioni razporejeni med verigami. 